\title{
PENGARUH PEMBERIAN SEDIAAN EMULGEL KITOSAN-EKSTRAK DAUN TAPAK DARA (CATHARANTUS ROSEUS (L.) G. DON.) DAN EMULGEL KITOSAN-EKSTRAK KULIT PISANG AMBON (MUSA PARADISIACA L.) UNTUK PENYEMBUHAN LUKA BAKAR PADA KELINCI
}

\author{
Mensie Martha Lovianie ${ }^{1}$ Susi Nurmanila ${ }^{2}$ Mustika $^{3}$ \\ ${ }^{123}$ STIKes Borneo Cendekia Medika Pangkalan Bun \\ 1email: mensiemartha34@gmail.com, ${ }^{2}$ email : Susinurmanilajoe891@gmail.com, \\ ${ }^{3}$ email : Ika.mukhlis16@gmail.com
}

\begin{abstract}
ABSTRAK
Kesehatan adalah suatu masalah yang sangat kompleks dan saling berkaitan dengan masalah-masalah lain di luar kesehatan. Banyak faktor yang mempengaruhi kesehatan, salah satu masalah kesehatan yang menyerang sistem perlindungan tubuh paling luar, yaitu kulit. Luka bakar pada kulit, luka bakar dapat merusak jaringan otot, tulang, pembuluh darah dan jaringan epidermis (Rismana et al., 2013). Daun tapak dara (Catharantus roseus (L.) G. Don.) telah dibuktikan berkhasiat sebagai diuretik, hipotensif, sedatif, hemostatis yang diketahui mengandung alkaloid, flavonoid, saponin, dan tanin (Dewi et al., 2013).

Kulit pisang ambon (Musa paradisiaca L.) memiliki beberapa efek farmakologi, seperti sebagai obat diare, uremia, hipertensi, disentri, diabetes dan luka bakar. Selain itu, tanaman pisang juga dapat digunakan untuk mengurangi reaksi inflamasi, nyeri, dan mengatasi gigitan ular serta mampu menyembuhkan luka bakar (Imam and Akter, 2011). Kulit pisang mengandung flavonoid, tanin, dan saponin (akpuaka and ezem, 2011). Pada penelitian ini digunakan hewan uji kelinci yang dibagi menjadi 6 kelompok dan masing-masing diberi perlakuan berbeda. Setiap kelinci dibuat luka bakar pada bagian punggung kiri dan kanan. Kemudian, kelinci yang telah dibuat luka bakar diberikan perlakuan dengan pengolesan bioplacenton, placebo, formulasi I (10\% dan $15 \%)$ dan formulasi II (20\% dan 30\%). Lalu mengamati dan mencatat pengecilan diameter luka bakar setiap hari. Sediaan emulgel kitosan-ekstrak daun tapak dara yang efektif untuk penyembuhan luka bakar pada kelinci dengan konsentasi ekstrak 30\% dan emulgel kitosan ekstrak kulit buah pisang ambon (Musa Paradisiaca L.) dengan konsentrai ekstrak 20\%.
\end{abstract}

Kata Kunci: Ekstrak Daun Tapak Dara (Catharantus Roseus (L.) G. Don.), Ekstrak Kulit Buah Pisang Ambon (Musa Paradisiaca L.), Luka Bakar. 


\title{
THE INFLUENCE OF THE PREPARATION EMULGEL KITOSAN-EKSTRAK LEAVES TREAD VIRGIN (CATHARANTUS ROSEUS (. L) G.DON.) AND THE SKIN OF A BANANA AMBON (EMULGEL KITOSAN-EKSTRAK MUSA PARADISIACA. L) FOR HEALING BURNS ON RABBITS
}

\begin{abstract}
Health is a a really complex problem and intertwined with the problems other than health. A lot of factors affect health, one of the problems health attack the system of patronage the body most outside, the chapters are skin. Burns on the skin, burns can damage muscle tissue, bone, vessels the blood and tissues the epidermis (rismana et al., 2013). Leaves tread virgin (catharantus roseus (l.) G. Don.) having been demonstrated efficacious as diuretic, hipotensif, sedative, hemostatis known contain the alkaloid, flavonoid, saponin, and tannin (goddess of et al., 2013). The skin of a banana ambon moses paradisiaca l.) has a number its pharmacological effects, such as drug diarrhea, uremia, hypertension, dysentery, diabetes and burns. In addition, banana plants can be used to reduce an inflammatory reaction, pain and handle a snake bite and able to heal burns (priests and akter, 2011). A banana peel containing flavonoid, tannin, and saponin (akpuaka and ezem, 2011). On this research used of animals tested rabbits are divided into groups and 6 given different treatment.Every bunny made burns on their backs left and right.Then, a rabbit that has been made burns given treatment by pengolesan bioplacenton, , placebo formulations I (10\% and $15 \%)$ and formulation II (20\% and $30 \%$ ).And observing and recording diminution diameter burns every day. Emulgel preparation kitosan-ekstrak leaves tread wench is effective for healing burns in a rabbit with konsentasi extract $30 \%$ and emulgel kitosan extract banana skins of ambon (moses paradisiaca l.) with konsentrai extract $20 \%$.
\end{abstract}

Key words: Extract leaves tread virgin (catharantus roseus (l.) G. Don.), extract the skin of a banana ambon moses paradisiaca l.), burns.

\section{PENDAHULUAN}

Unit luka bakar RSU Dr. Soetomo Surabaya didapatkan statistik menunjukkan bahwa $60 \%$ luka bakar terjadi karena kecelakaan rumah tangga, 20\% karena kecelakaan kerja, dan $20 \%$ sisanya karena sebab-sebab lain, misalnya bus terbakar, ledakan bom, dan gunung meletus.

Penanganan pada penderita luka bakar salah satunya dapat dengan menggunakan sediaan topikal, karena jaringan yang mengeras akibat luka bakar tidak dapat ditembus dengan pemberian obat dalam bentuk sediaan oral maupun parenteral. Sediaan topikal yang biasa digunakan oleh masyarakat adalah sediaan emulgel. Stabilitas emulgel tergantung dari sifat fisiknya antara lain $\mathrm{pH}$, homogenitas, daya sebar, daya lekat dan organoleptis. Sediaan emulgel diperlukan penambahan gelling agent untuk mendapatkan stabilitas sistem yang baik.

Pemilihan gelling agent sangat menentukan hasil akhir sediaan. Kitosan merupakan polimer alam dari hewan yang sering digunakan untuk 
bahan obat dan memiliki sifat adesif sehingga mampu memperbaiki sifat fisik emulgel dengan cara meningkatkan daya lekat pada kulit. Bahan alam yang lain dan digunakan untuk luka bakar dari tumbuhan yaitu daun tapak dara dan kulit pisang ambon.

Daun tapak dara (Catharantus roseus (L.) G.Don.) telah dibuktikan berkhasiat sebagai diuretik, hipotensif, sedatif, hemostatis yang diketahui mengandung alkaloid, flavonoid, saponin, dan $\operatorname{tanin}^{1}$. Alkaloid mempunyai kemampuan sebagai antibakteri. Flavonoid berfungsi sebagai antibakteri, antiinflamasi dan juga sebagai antioksidan. Saponin memiliki kemampuan sebagai pembersih dan antiseptik berfungsi membunuh kuman atau mencegah pertumbuhan mikroorganisme, biasatimbul pada luka sehingga luka tidak mengalami infeksi yang berat. Tanin juga berfungsi sebagai antibakteri dan antifungi ${ }^{2}$.

Kulit pisang ambon (Musa paradisiaca L.) memiliki beberapa efek farmakologi, seperti sebagai obat diare, uremia, hipertensi, disentri, diabetes dan luka bakar. Selain itu, tanaman pisang juga dapat digunakan untuk mengurangi reaksi inflamasi, nyeri, dan mengatasi gigitan ular serta mampu menyembuhkan luka bakar. Kulit pisang mengandung flavonoid, tanin, dan saponin $^{3}$. Flavonoid dipercaya sebagai salah satu komponen penting dalam proses penyembuhan luka. Flavonoid menginhibisi pertumbuhan fibroblast sehingga memberikan keuntungan pada perawatan luka (Hidayati, 2014).

Tanin memiliki kemampuan sebagai antimikroba serta dapat meningkatkan epitelialisasi. Flavonoid dan tanin juga bertanggung jawab dalam proses remodelling (james and Friday, 2010). Saponin dapat mempercepat proses penyembuhan luka akibat adanya aktivitas antimikroba dan bersifat sebagai antioksidan. Saponin juga dapat meningkatkan kandungan kolagen serta mempercepat proses epitelialisasi. Tujuan dari penelitian ini adalah untuk mengetahui efektivitas sediaan emulgel kitosan-ekstrak daun tapak dara (Catharantus roseus (L.) G.Don.) dan emulgel kitosan-ekstrak kulit buah pisang ambon (musa paradisia lamk) untuk penyembuhan luka bakar pada kelinci.

\section{METODE PENELITIAN}

Kategori penelitian tentang pengaruh pemberian sediaan emulgel kitosanekstrak daun tapak dara (Catharantus roseus (L.) G. Don.) dan emulgel kitosan-ekstrak kulit pisang ambon (Musa paradisiaca L.) untuk penyembuhan luka bakar pada kelinci adalah jenis penelitian experimental murni true experimental

Pembuatan simplisia, ekstrak daun tapak dara (Catharantus roseus (L.) G. Don.) dan ekstrak kulit pisang ambon (Musa paradisiaca L.)

\section{Pembuatan simplisia Daun Tapak Dara dan Kulit Pisang Ambon}

Daun tapak dara segar dicuci bersih dengan air mengalir, ditiriskan kemudian dirajang kecil-kecil dengan menggunakan pisau, selanjutnya diangin-anginkan selama 3 hari pada suhu kamar kemudian dilanjutkan pengeringan dengan menggunakan lemari pengering dengan suhu $40^{\circ}$ selama 3 hari. Setelah kering daun 
tapak dara kemudian dihaluskan dengan menggunakan blender dan diayak dengan ayakan 200 mesh (Soriton et al., 2014).

Kulit pisang ambon (Musa paradisiaca L.) dicuci dengan air PDAM dan dibilas dengan air mengalir, kemudian diiris tipis-tipis. Selanjutnya kulit pisang dihaluskan menggunakan belender, kulit pisang yang telah halus kemudian disimpan dalam wadah kaca tertutup rapat, terlindung dari sinar matahari serta disimpan pada suhu kamar.

\section{Pembuatan ekstrak}

Pembuatan ekstrak etanol daun tapak dara yaitu menggunakan metode maserasi. Kurang lebih 500 g serbuk simplisia dimasukkan dalam panci kemudian diberi etanol $70 \%$ sebanyak 3,75 L. Maserasi dilakukan selama 5 hari dalam ruangan yang terlindung dari cahaya matahari dan sering dilakukan pengadukan.

Pengadukan ini bertujuan untuk meratakan konsentrasi yang sebesarbesarnya antara larutan di dalam sel dengan diluar sel, setelah itu ekstrak yang diperoleh disaring dengan menggunakan kertas saring biarkan hingga ekstrak yang diperoleh menjadi jernih, selanjutnya ekstrak diuapkan dengan menggunakan waterbath pada temperatur $50^{\circ} \mathrm{C}$ hingga diperoleh ekstrak kental (Susilo et al., 2013).

Ekstrak etanol kulit pisang ambon dilakukan dengan metode maserasi dengan pelarut etanol $70 \%$ sebanyak $2.000 \mathrm{ml}$. Sejumlah $1 \mathrm{~kg}$ kulit pisang ambon yang telah diblender menjadi halus dimasukkan kedalam wadah kaca lalu direndam dengan pelarut etanol $70 \%$, selama 5 hari dan dilakukan pengadukan sesering mungkin, kemudian dilakukan penyaringan menggunakan kertas saring. Maserat berupa ekstrak cair yang kemudian dipanaskan sambil diaduk hingga diperoleh ekstrak agak kental berwarna hijau kehitaman yang sangat pekat.

\section{Skrining fitokimia ekstrak daun tapak dara (Catharantus roseus (L.) G. Don.) dan ekstrak kulit pisang ambon (Musa paradisiaca L.)}

Skrining fitokimia dilakukan dengan mengidentifikasi kandungan flavonoid, saponin, tanin dan alkaloid.

Formulasi sediaan emulgel-ekstrak daun tapak dara (Catharantus roseus (L.) G. Don.) dan emulgel ekstrak kulit pisang ambon (Musa paradisiaca $\mathbf{L}$.)

Pembuatan gelling agent kitosan

Gel kitosan dibuat dengan melarutkan 2 g kitosan di dalam $100 \mathrm{~mL} \mathrm{1 \%} \mathrm{(b/b)}$ asam asetat kemudian dipanaskan sambil diaduk hingga mengental dan berbentuk gel.

Formulasi sediaan

Formulasi emulgel kitosan-ekstrak daun tapak dara

Disiapkan semua bahan yang akan digunakan. Bahan ditimbang sesuai dengan formula yang ada. Langkah pertama ekstrak daun tapak dara 15\% dimasukkan kedalam cawan bersamaan dengan span 80 dan VCO lalu dipanaskan, kemudian panaskan juga tween 80 secara terpisah, setelah panas baru dicampur ke cawan yang berisi ekstrak, VCO dan span 80. Langkah kedua sambil menunggu bahan yang dipanaskan. Siapkan mortir gerus karbopol, selanjutnya masukkan kitosan sedikit demi sedikit sambil 
digerus dan mencampurkan propilenglikol. Terakhir campurkan semua bahan yang dipanaskan secara perlahan kedalam mortir yang berisi kitosan, propilenglikol dan karbopol. Gerus sampai homogen sehingga membentuk emulgel. Prosedur yang sama juga dilakukan pada ekstrak dengan konsentrasi 30\%. Formulasi emulgel ekstrak daun tapak dara dapat dilihat pada tabel 1 dibawah ini:

Tabel 1. Formulasi Sediaan Emulgel Kitosan-Ekstrak Daun Tapak Dara

\begin{tabular}{cccc}
\hline \multirow{2}{*}{$\begin{array}{c}\text { Nama } \\
\text { Bahan }\end{array}$} & \multicolumn{3}{c}{ Kormulasi dan } \\
& $\begin{array}{c}\text { Formu } \\
\text { lasi 1 }\end{array}$ & $\begin{array}{c}\text { Formu } \\
\text { lasi 2 }\end{array}$ & $\begin{array}{c}\text { Formu } \\
\text { lasi 3 }\end{array}$ \\
\hline $\begin{array}{c}\text { Eksrak } \\
\text { daun }\end{array}$ & & & \\
tapak & - & $15 \%$ & $30 \%$ \\
dara & & & \\
VCO & $5 \%$ & $5 \%$ & $5 \%$ \\
Tween 80 & 0,616 & 0,616 & 0,616 \\
& $\%$ & $\%$ & $\%$ \\
Span 80 & 2,384 & 2,384 & 2,384 \\
Propileng & $\%$ & $\%$ & $\%$ \\
likol & $5 \%$ & $5 \%$ & $5 \%$ \\
Kitosan & $69,6 \%$ & $57,6 \%$ & $45,6 \%$ \\
Karbopol & $17,4 \%$ & $14,4 \%$ & $11,4 \%$ \\
\hline Formulasi & emulgel & kitosan-ekstrak \\
kulit pisang ambon & \multicolumn{2}{c}{}
\end{tabular}

Menimbang bahan-bahan yang diperlukan seperti yang tertera pada tabel 2 menimbang bahan bahan yang pertama. Siapkan mortir, gerus karbopol selanjutnya masukkan kitosan sedikit demi sedikitsambil digerus dan campurkan propilenglikol. Untuk ekstrak kulit pisang ambon masukkan kedalam cawan yang kemudian campur dengan span 80 dan VCO dipanaskan, tidak dicampur dengan tween 80 . Tween 80 juga dipanaskan sendiri setelah panas baru dicampur kecawan yang berisi ekstrak, VCO dan span 80 . Terakhir campurkan semua bahan yang dipanaskan secara perlahan kedalam mortir yang berisi kitosan, propilenglikol dan karbopol dan gerus sampai homogen sehingga membentuk emulgel. Formulasi sediaan emulgel dapat dilihat pada tabel 2 .

Tabel 2. Formulasi emulgel kitosanekstrak kulit buah pisang ambon

\begin{tabular}{cccc}
\hline Nama & \multicolumn{3}{c}{ Formula dan komposisi (\% } \\
Bahan & \multicolumn{3}{c}{ b/v) } \\
\cline { 2 - 4 } & $\begin{array}{c}\text { Plaseb } \\
\text { o }\end{array}$ & F 1 & F 2 \\
\hline Ekstrak & - & $10 \%$ & $20 \%$ \\
kulit & & & \\
pisang & & & \\
ambon & & & \\
Propilen & $5 \%$ & $5 \%$ & $5 \%$ \\
glikol & & & \\
VCO & $5 \%$ & $5 \%$ & $5 \%$ \\
Tween 80 & 0,616 & 0,616 & 0,616 \\
& $\%$ & $\%$ & $\%$ \\
Span 80 & 2,384 & 2,384 & 2,384 \\
& $\%$ & $\%$ & $\%$ \\
Kitosan & $69,6 \%$ & $61,6 \%$ & $53,6 \%$ \\
Karbopol & $17,4 \%$ & $15,4 \%$ & $13,4 \%$ \\
Add & 100 & 100 & 100 \\
(kitosan & \multicolumn{3}{c}{} \\
$\quad \&$ & & & \\
Karbopol & & & \\
$\quad$ ) & & & \\
\hline
\end{tabular}

Uji efektivitas penyembuhan luka bakar kelinci yang diinduksi luka.

Pada penelitian ini digunakan hewan uji kelinci yang dibagi menjadi kelompok dan masing-masing diberi perlakuan berbeda. Sebelum digunakan sebagai hewan uji, semua kelinci dipelihara terlebih dahulu selama \pm satu minggu untuk penyesuaian lingkungan dan mengontrol kesehatan, berat badan serta diberi makan yang cukup setiap harinya. Setiap kelinci 
dibuat luka bakar pada bagian punggung kiri dan kanan. Punggung kelinci dibersihkan dari bulu-bulu dengan cara dicukur hingga bersih.

Lakukan anestesi pada kelinci menggunakan etil klorida secara lokal. Kemudian punggung kelinci diinduksi menggunakan logam panas berdiameter $\pm 3 \mathrm{~cm}$ dengan cara lempeng logam dipanaskan di api biru selama 3 menit lalu ditempelkan pada punggung kelinci selama 10 detik. Kemudian, kelinci yang telah dibuat luka bakar diberikan perlakuan dengan pengolesan bioplacenton, placebo, formulasi I (10\% dan $15 \%)$ dan formulasi II (20\% dan 30\%). Lalu mengamati dan mencatat pengecilan diameter luka bakar setiap hari.

\section{Pengamatan Luka Bakar}

Kelinci diinduksi luka bakar, kemudian kelinci diberi perlakuan sesuai kelompok masing-masing. Perlakuan ini diberikan setiap dua kali sehari pagi dan sore hari.

Data yang diperoleh dari penelitian berupa diameter luka bakar $(\mathrm{cm})$ yang diukur dengan jangka sorong. Diameter luka bakar yang diperoleh dihitung dengan menggunakan rumus:

$$
\mathrm{dx}=\frac{\mathrm{d} 1+\mathrm{d} 2+\mathrm{d} 3+\mathrm{d} 4}{4}
$$

Keterangan :

$\mathrm{dx}$ : diameter luka bakar hari-x

d1 : diameter 1

d2 : diameter 2

d3 : diameter 3

$\mathrm{d} 4$ : diameter 4

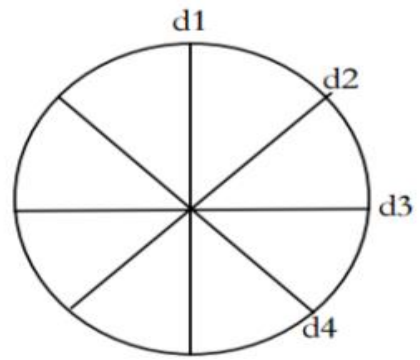

Gambar 1. Cara Mengukur Diameter Luka Bakar

\section{Analisis Data}

Secara statistik menggunakan metode ANOVA (Analysis Of Variant) dengan $\alpha \quad 0,05$ atau $5 \%$ dengan rumus perhitungan (Rumayar). Menghitung presentasi penyembuhan luka bakar dengan rumus berikut:

$$
P \%=\frac{d o-d x}{d o} \times 100 \%
$$

Keterangan:

$\mathrm{P} \%$ :Presentasi penyembuhan luka bakar

Do :Diameter luka bakar pada hari pertama

Dx Diameter luka bakar pada hari pengamatan (Mappa et al., 2013).

Analisis data yang digunakan merupakan analisis inferensial yang meliputi uji normalitas dengan menggunakan uji shapiro-wilk dan uji homogenitas dengan menggunakan levene test. Data yang terdistribusi normal dilanjutkan dengan uji ANOVA (Analysis Of Variant) yang menandakan kelompok penelitian memiliki perbedaan yang bermakna, maka untuk mengetahui adanya perbedaan antar kelompok perlakuan yaitu dilanjutkan dengan uji LSD (Least Significant Difference) dengan nilai signifikan $\mathrm{p}<0,05$.

\section{Hasil dan Pembahasan}




\section{Pengujian Skrining Fitokimia Ekstrak Daun Tapak Dara}

Kandungan senyawa yang dianalisis dalam penelitian ini meliputi senyawa alkaloid, flavonoid, tanin, dan saponin. Pengujian fitokimia dimaksudkan untuk mengetahui senyawa-senyawa yang terdapat dalam daun tersebut setelah mengalami proses ekstraksi dengan melihat ada tidaknya reaksi pengendapan dan perubahan warna yang terjadi pada uji tabung. Hasil skrining fitokimia yang dilakukan terhadap ekstrak daun tapak dara dapat dilihat pada tabel 3 .

Tabel 3. Hasil Skrining Fitokimia Ekstrak Daun Tapak Dara

\begin{tabular}{|c|c|c|c|}
\hline $\begin{array}{c}\text { Golong } \\
\text { an } \\
\text { senyaw } \\
\text { a }\end{array}$ & Reagen & $\begin{array}{c}\text { Has } \\
\text { il }\end{array}$ & $\begin{array}{c}\text { Keterang } \\
\text { an }\end{array}$ \\
\hline $\begin{array}{c}\text { Uji } \\
\text { alkaloid }\end{array}$ & $\begin{array}{c}\mathrm{HCl}+ \\
\text { Dragendr } \\
\text { off }\end{array}$ & $(+)$ & $\begin{array}{c}\text { Endapan } \\
\text { coklat } \\
\text { muda }\end{array}$ \\
\hline $\begin{array}{c}\text { Uji } \\
\text { flavono } \\
\text { id }\end{array}$ & $\begin{array}{c}\mathrm{HCl} \\
\text { pekat + } \\
\text { serbuk } \\
\mathrm{Mg}+ \\
\text { Amil } \\
\text { alkohol }\end{array}$ & $(+)$ & $\begin{array}{c}\text { Warna } \\
\text { jingga / } \\
\text { orange }\end{array}$ \\
\hline $\begin{array}{c}\mathrm{Uji} \\
\operatorname{tanin}\end{array}$ & $\mathrm{FeCl}$ & $(+)$ & $\begin{array}{c}\text { Terbentu } \\
\text { k warna } \\
\text { biru tua } \\
\text { atau } \\
\text { hijau } \\
\text { kehitama } \\
\text { n }\end{array}$ \\
\hline $\begin{array}{c}\text { Uji } \\
\text { saponin }\end{array}$ & $\begin{array}{c}\text { Air } \\
\text { panas+ } \\
\mathrm{HCl}\end{array}$ & $(+)$ & $\begin{array}{c}\text { Terdapat } \\
\text { busa } \\
\text { yang } \\
\text { bertahan } \\
\pm 5 \text { menit } \\
\text { pada } \\
\text { lapisan } \\
\text { atas } \\
\end{array}$ \\
\hline
\end{tabular}

Keterangan :

$(+)$ memberikan hasil positif

(-) memberikan hasil negatif

Hasil uji skrining fitokimia ekstrak daun tapak dara yang terdapat pada tabel 3 menunjukkan bahwa ekstrak mengandung senyawa alkaloid, flavonoid, tanin, dan saponin. Hasil pengujian kualitatif pada senyawa alkaloid didapatkan hasil positif karena menghasilkan endapan coklat muda yang terbentuk dan menjadi reaksi antar kompleks dan ion logam dari reagen dengan senyawa alkaloid.

Menurut Rijayanti (2014) mekanisme kerja alkaloid sebagai antibakteri yaitu dengan cara mengganggu komponen penyusun peptidoglikan pada sel bakteri, sehingga lapisan dinding sel tidak terbentuk secara utuh dan menyebabkan kematian sel tersebut.

Hasil pengujian flavonoid menunjukkan ekstrak daun tapak dara didapatkan hasil positif karena menghasilkan warna jingga/orange. Handayani et al (2016) mengatakan senyawa yang ada pada flavonoid bisa melancarkan peredaran darah ke seluruh tubuh dan mencegah terjadinya penyumbatan pembuluh darah, mengandung antiinflamasi juga berfungsi sebagai antioksidan, dan membantu mengurangi rasa sakit jika terjadi pendarahan atau pembengkakan.

Menurut Larissa et al (2017) flavonoid memiliki mekanisme kerja dalammenghambat pertumbuhan bakteri dengan cara inaktivasi protein pada membran sel, dapat menghambat jalur lipoksigenase dan siklooksigenase dalam metabolisme asam arakidonat.

Hasil pengujian saponin menunjukkan ekstrak daun tapak dara didapatkan 
hasil positif dan terdapat busa yang bertahan \pm 5 menit pada lapisan atas. Yuliastuti et al (2017) mengatakan timbulnya busa inilah yang menjadikan mudahnya indikasi adanya saponin ketika dilakukan uji fitokimia. Menurut Larissa et al (2017) senyawa saponin berperan sebagai antibakteri dengan cara menurunkan tegangan permukaan dinding sel dan apabila berinteraksi dengan dinding sel bakteri maka dinding sel tersebut akan lisis.

Mekanisme kerja saponin yaitu akan mengganggu tegangan permukaan dinding sel, maka pada saat tegangan permukaan terganggu zat antibakteri akan masuk dengan mudah kedalam sel dan akan mengganggu metabolisme hingga akhirnya terjadilah kematian bakteri.

Hasil pengujian tanin yang diperoleh membentuk warna biru tua atau hijau kehitaman. Perubahan warna ini disebabkan $\mathrm{FeCl}$ bereaksi dengan salah satu gugus hidroksil yang ada pada senyawa lain. Hasil reaksi itulah yang akhirnya menimbulkan warna dan menunjukkan ekstrak daun tapak dara positif mengandung tanin.

Menurut Ngajowet al (2013) tanin memiliki aktifitas sebagai antibakteri yang berhubungan dengan kemampuannya untuk menginaktifkan adhesin sel mikroba juga menginaktifkan enzim dan menggangu transport protein pada lapisan dalam sel. Tanin juga mempunyai target pada polipeptida dinding sel sehingga pembentukan dinding sel menjadi kurang sempurna. Hal ini menyebabkan sel bakteri menjadi lisis karena tekanan osmotik maupun fisik sehingga sel bakteri akan mati.

\section{Ekstrak Kulit Pisang Ambon}

Pengujian fitokimia dimaksudkan untuk mengetahui senyawa-senyawa yang terdapat dalam kulit buah tersebut setelah mengalami proses ekstraksi dan fraksinasi dengan melihat ada tidaknya reaksi pengendapan dan perubahan warna yang terjadi pada tabung uji. Kandungan dalam ekstrak kulit pisang ambon diidentifikasi dengan cara skrining fitokimia. Kandungan senyawa yang diuji antara lain golongan flavonoid, Tanin, dan Saponin. Hasil skrining fitokimia yang dilakukan terhadap ekstrak kulit pisang ambon dapat dilihat pada tabel 4 .

Tabel 4. Hasil Skrining Fitokimia kulit pisang ambon

\begin{tabular}{lllll}
\hline Golo & Rea & Ha & Ketera & Gambar \\
ngan & gen & sil & ngan & \\
senya & & & & \\
wa & & & &
\end{tabular}

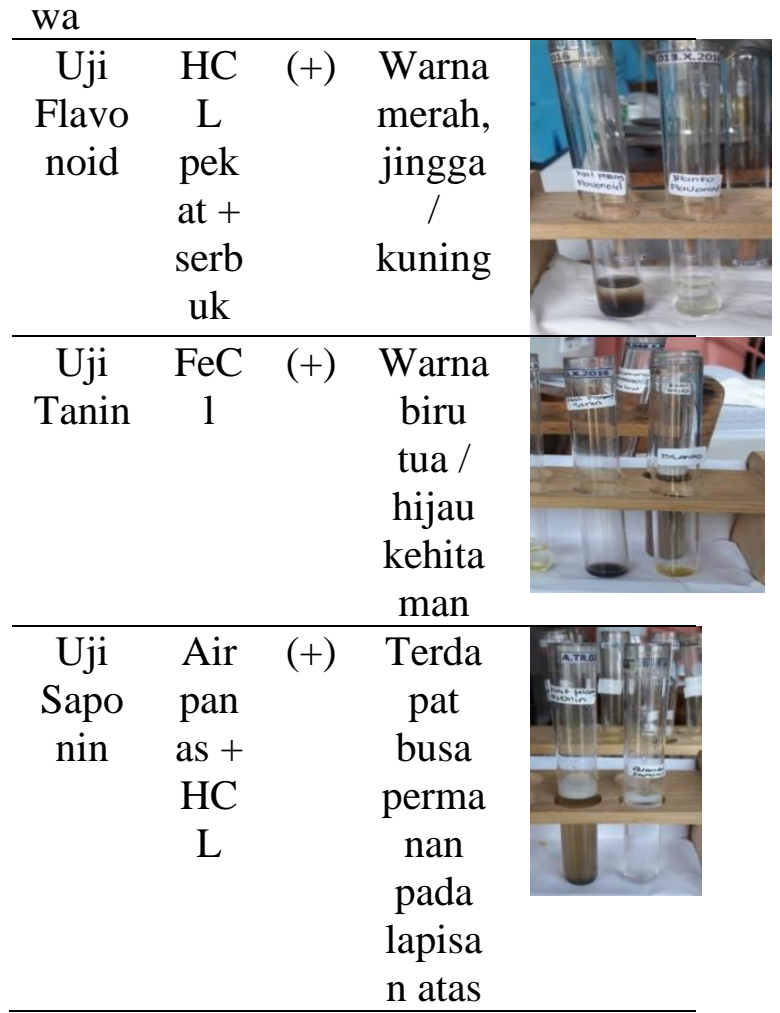

Keterangan : (+) memberikan hasil positif

Pada penelitian ini uji skrining fitokimia flavonoid dihasilkan hasil 
yang positif setelah penambahan $\mathrm{HCl}$ pekat karena menunjukkan warna merah jingga/kuning yang menunjukkan hasil positif mengandung flavonoid pada ekstrak kulit buah pisang ambon.

Menurut Sentat dan Pangestu, 2016 Penambahan $\mathrm{HCl}$ pekat dalam uji flavonoid untuk menghidrolisis flavonoid menjadi aglikonnya. Reduksi dengan $\mathrm{Hcl}$ pekat dan $\mathrm{Mg}$ ini menghasilkan senyawa komplek yang berwarna merah, jingga atau kuning. jika hasil yang didapat berwarna merah, jingga atau kuning maka uji fitokimia pada ekstrak kulit buah pisang ambon memberikan hasil positif mengandung senyawa flavonoid.

Senyawa Flavonoid memiliki peran penting dalam proses penyembuhan luka, Flavonoid sebagai antibakteri yang membantu dalam mencegah berkembangbiaknya bakteri pada luka yang terbentuk, serta berperan dalam proses epitealisasi sebagai penstimulasi regenerasi jaringan kulit pada luka dan sebagai antiinflamasi. (Rohmawati, N., 2008).

Uji skrining fitokimia Tanin menunjukakan hasil yang positif setelah penambahan $\mathrm{FeCl}_{3}$ karena menunjukkan warna biru tua/hijau kehitaman yang menunjukkan hasil positif mengandung Tanin pada ekstrak kulit buah pisang ambon.

Menurut Sentat dan Pangestu, 2016 Identifikasi Uji Tanin dengan meneteskan $\mathrm{FeCl}_{3} 1$ sampai 2 tetes kedalam tabung reaksi. Bila terbentuk warna biru tuaatau hijau kehitaman maka uji fitokimia pada ekstrak kulit pisang ambon memberikan hasil positif mengandung senyawa Tanin.
Hasil yang diperoleh dari Uji skrining fitokimia saponin menunjukakan hasil yang positif setelah penambahan air panas + HCL karena terbentuk busa setelah dikocok selama 10 detik dan didiamkan tidak kurang 10 menit terdapat busa permanen pada lapisan atas yang menunjukkan hasil positif mengandung saponin pada ekstrak kulit buah pisang ambon.

Menurut Sentat dan Pangestu, 2016 Identifikasi saponin dilakukan sepuluh tetes ekstrak etanol kulit pisang ambon dimasukkan kedalam tabung ditambahkan $10 \mathrm{ml}$ air panas dan dikocok selama 15 menit lalu ditambahkan 1 sampai 2 tetes $\mathrm{HCl} 2 \mathrm{~N}$. Jika terbentuk busa permanen memberikan indikasi adanya saponin.

Senyawa saponin yang terkandung sebagai pembentuk kolagen dan antikoagulan yang mampu menghambat penggumpalan darah. Senyawa saponin sangat efektif untuk membersihkan luka terutama luka terbuka (Rohmawati, N., 2008).

\section{Pengujian Efektivitas Sediaan Emulgel Ekstrak Daun Tapak Dara untuk Penyembuhan Luka Bakar Emulgel Kitosan Ekstrak Daun Tapak Dara}

Hasil penelitian yang diperoleh berupa rata-rata penurunan diameter luka bakar pada kontrol positif, kontrol negatif, emulgel ekstrak daun tapak dara $15 \%$ dan $30 \%$ dapat dilihat pada tabel 5 .

Tabel 5. Persentase Rata-Rata Penurunan Diameter Luka Bakar 
Keterangan:

P\%: Persentase penurunan diameter luka bakar pada hari ke 1-24

\begin{tabular}{|c|c|c|c|}
\hline $\begin{array}{c}\text { I }) \\
\text { Perlakuan } \\
\text { Sediaan }\end{array}$ & $\begin{array}{c}(\mathrm{J}) \\
\text { Perlakuan } \\
\text { Sediaan }\end{array}$ & $\begin{array}{c}\text { Mean } \\
\text { Difference } \\
\text { (I-J) }\end{array}$ & Sig. \\
\hline \multirow{5}{*}{$\begin{array}{l}\text { Kontrol } \\
\text { Positif }\end{array}$} & $\begin{array}{l}\text { Kontrol } \\
\text { Negatif }\end{array}$ & $26,07667^{*}$ & ,001 \\
\hline & $\begin{array}{l}\text { Emulgel } \\
\text { Ekstrak } \\
\text { Daun }\end{array}$ & 10,70333 & ,060 \\
\hline & Tapak & & \\
\hline & $\begin{array}{l}\text { Dara } 15 \% \\
\text { Emuloel }\end{array}$ & 51000 & \\
\hline & $\begin{array}{l}\text { Ekstrak } \\
\text { Daun } \\
\text { Tapak } \\
\text { Dara } 30 \%\end{array}$ & & \\
\hline \multirow{4}{*}{$\begin{array}{l}\text { Kontrol } \\
\text { Negatif }\end{array}$} & $\begin{array}{l}\text { Kontrol } \\
\text { Positif }\end{array}$ & $\begin{array}{l} \\
26,07667^{*}\end{array}$ & ,001 \\
\hline & $\begin{array}{l}\text { Emulgel } \\
\text { Ekstrak } \\
\text { Daun }\end{array}$ & $-\overline{15,37333^{*}}$ & ,014 \\
\hline & $\begin{array}{l}\text { Tapak } \\
\text { Dara } 15 \%\end{array}$ & & \\
\hline & $\begin{array}{l}\text { Emulgel } \\
\text { Ekstrak } \\
\text { Daun } \\
\text { Tapak } \\
\text { Dara 30\% }\end{array}$ & $\begin{array}{l} \\
23,56667^{*}\end{array}$ & ,001 \\
\hline \multirow{3}{*}{$\begin{array}{l}\text { Emulgel } \\
\text { Ekstrak } \\
\text { Daun } \\
\text { Tapak } \\
\text { Dara } 15 \%\end{array}$} & $\begin{array}{l}\text { Kontrol } \\
\text { Positif }\end{array}$ & $-10,70333$ & ,060 \\
\hline & $\begin{array}{l}\text { Kontrol } \\
\text { Negatif }\end{array}$ & $15,37333^{*}$ & ,014 \\
\hline & $\begin{array}{l}\text { Emulgel } \\
\text { Ekstrak } \\
\text { Daun } \\
\text { Tapak } \\
\text { Dara 30\% }\end{array}$ & $-8,19333$ & ,133 \\
\hline \multirow{3}{*}{$\begin{array}{l}\text { Emulgel } \\
\text { Ekstrak } \\
\text { Daun } \\
\text { Tapak } \\
\text { Dara 30\% }\end{array}$} & $\begin{array}{l}\text { Kontrol } \\
\text { Positif }\end{array}$ & $-2,51000$ & ,622 \\
\hline & $\begin{array}{l}\text { Kontrol } \\
\text { Negatif }\end{array}$ & $23,56667^{*}$ & ,001 \\
\hline & $\begin{array}{l}\text { Emulgel } \\
\text { Ekstrak } \\
\text { Daun } \\
\text { Tapak } \\
\text { Dara 15\% }\end{array}$ & 8,19333 & ,133 \\
\hline
\end{tabular}

\begin{tabular}{|c|c|c|c|}
\hline $\begin{array}{l}\text { Perla } \\
\text { kuan }\end{array}$ & $\begin{array}{c}\text { Hari } \\
\text { ke- } \\
1 \pm S D\end{array}$ & $\begin{array}{c}\text { Hari } \\
\text { ke- } \\
24 \pm S \\
D\end{array}$ & $\begin{array}{c}\mathrm{P} \% \pm \mathrm{S} \\
\mathrm{D}\end{array}$ \\
\hline $\begin{array}{l}\text { Kontr } \\
\text { ol } \\
\text { Positi } \\
\text { f }\end{array}$ & $\begin{array}{l}20,65 \\
\pm 1,50\end{array}$ & $\begin{array}{c}2,59 \\
\pm 0,81\end{array}$ & $\begin{array}{r}87,60 \\
\pm 2,91\end{array}$ \\
\hline $\begin{array}{c}\text { Kontr } \\
\text { ol } \\
\text { Negat } \\
\text { if }\end{array}$ & $\begin{array}{l}21,09 \\
\pm 1,79\end{array}$ & $\begin{array}{c}8,08 \\
\pm 1,91\end{array}$ & $\begin{array}{r}61,53 \\
\pm 9,83\end{array}$ \\
\hline $\begin{array}{c}\text { Emul } \\
\text { gel } \\
15 \%\end{array}$ & $\begin{array}{c}22,90 \pm \\
3,15\end{array}$ & $\begin{array}{c}5,22 \\
\pm 0,33\end{array}$ & $\begin{array}{r}76,90 \\
\pm 3,77\end{array}$ \\
\hline $\begin{array}{c}\text { Emul } \\
\text { gel } \\
30 \%\end{array}$ & $\begin{array}{c}21,10 \pm \\
3,17\end{array}$ & $\begin{array}{r}3,25 \\
\pm 1,44\end{array}$ & $\begin{array}{r}85,09 \\
\pm 4,96\end{array}$ \\
\hline
\end{tabular}

Rata-rata penurunan diameter luka bakar untuk kontrol positif yaitu $(87,60 \%)$, kontrol negatif yaitu $(61,53 \%)$, rata-rata penurunan diameter luka bakar untuk emulgel $15 \%$ yaitu $(76,90 \%)$ dan rata-rata penurunan diameter luka bakar untuk emulgel $30 \%$ yaitu $(85,09 \%)$.

Berdasarkan data kontrol positif memiliki hasil presentasi penyembuhan luka bakar yang paling tinggi dibandingkan dengan seluruh kolompok, diikuti dengan emulgel ekstrak daun tapak dara 30\% yang hampir sama dengen kontrol positif pada emulgel ekstrak daun tapak dara $15 \%$ mengalami penurunan dibanding kontrol negatif emulgel tanpa ekstrak

*. The mean difference is significant at the 0.05 level.

Hasil LSD menunjukkan bahwa kontrol positif dengan kontrol negatif mempunyai nilai rata-rata 26,07 $(0,001)$ sehingga dia mempunyai perbedaan yang signifikan. Kontrol positif dengan emulgel $15 \%$ mempunyai nilai rata-rata 10,70 
$(0,060)$ sehingga tidak ada perbedaan yang signifikan atau hasilnya sama dengan kontrol positif. Kontrol positif dengan emulgel $30 \%$ mempunyai nilai rata-rata $2,51 \quad(0,622)$ sehingga ini menunjukkan tidak ada perbedaan yang signifikan.

Kontrol negatif dengan emulgel $15 \%$ mempunyai nilai rata-rata $-15,37$ $(0,014)$ sehingga dia mempunyai perbedaan yang signifikan, ini menunjukkan bahwa emulgel $15 \%$ memiliki efaktifitas yang sama atau hampir sama dengan kontrol positif. Kontrol negatif dengan emulgel $30 \%$ mempunyai nilai rata-rata $-23,56$ $(0,001)$ sehingga dia mempunyai perbedaan yang signifikan, bisa ditarik kesimpulan bahwa emulgel $30 \%$ efektif menurunkan diameter luka bakar, sedangkan untuk emulgel $15 \%$ dengan emulgel $30 \%$ mempunyai nilai rata-rata $-8,19(0,133)$ sehingga tidak ada perbedaan yang signifikan, jadi dapat ditarik kesimpulan bahwa emulgel 15\% dan emulgel $30 \%$ efektif untuk penyembuhan luka bakar.

\section{Emulgel Kitosan Ekstrak Kulit Pisang Ambon}

Hasil penelitian yang diperoleh berupa rata rata penurunan diameter luka dari pemberian ekstrak kulit buah pisang ambon (Musa Paradisiaca L.) Dengan konsentrasi $10 \%$ dan $20 \%$, pemberian

bioplacenton sebagai kontrol positif dan placebo sebagai kontrol negatif. Berikut ini adaah hasil penurunan diameter luka bakar pada kelinci selama 24 hari.

Tabel 7. Persentase Rata rata penurunan diameter luka bakar

\begin{tabular}{lccc}
\hline Perlakuan & $\begin{array}{c}\text { Hari } \\
\text { ke 1 }\end{array}$ & $\begin{array}{c}\text { Hari } \\
\text { ke 24 }\end{array}$ & P\% \\
\hline Kontrol & 24,33 & $3,60 \pm$ & $84,92 \pm$ \\
positif & \pm & 1,53 & 7,31 \\
& 1,54 & & \\
\hline Kontrol & 27,42 & 11,99 & $56,25 \pm$ \\
Negatif & \pm & $\pm 2,57$ & 2,72 \\
& 5,73 & & \\
\hline Emulgel & 21,30 & $5,04 \pm$ & $76,61 \pm$ \\
kulit & \pm & 1,85 & 7,60 \\
buah & 1,18 & & \\
pisang & & & \\
ambon & & & \\
$10 \%$ & & & \\
\hline $\begin{array}{l}\text { Emulgel } \\
\text { kulit }\end{array}$ & 26,40 & $4,17 \pm$ & $83,89 \pm$ \\
buah & \pm & 2,07 & 8,99 \\
pisang & 1,64 & & \\
ambon & & & \\
$20 \%$ & & & \\
\hline
\end{tabular}

Keterangan :

$\mathrm{P} \%$ : persenase penurunan diameter luka bakar pada hari ke 1-24

Hasil Uji ANOVA

Data yang diperoleh dianalisi menggunkan metode Anova satu arah (One Way ANOVA) untuk melihat apakah emulgel yang dibuat memiliki pengaruh terhadap penyembuhan luka bakar.

Data dilanjutkan dengan uji LSD untuk mengetahui perbedaan bermakna pada masing masing perlakuan sehingga dapat disimpulkan emulgel kitosan ekstrak kulit pisang ambon $10 \%$ dan $20 \%$ efektif dalam penyembuhan luka bakar.

\section{DAFTAR PUSTAKA}

Dewi Ida Ayu, L.P., I Made, D., I Ketut, A.D., 2013. Bioaktivitas Ekstrak Daun Tapak Dara (Catharanthus 
Roseus) Terhadap Periode Epitelisasi Dalam Proses Penyembuhan Luka Pada Tikus Wistar. 58-75.

Handayani, F., Triswanto, S., 2016. Uji Aktivitas Ekstrak Etanol Daun Kersen (Muntingia Calabura L.) Terhadap Penyembuhan Luka Bakar Pada Kulit Mencit Putih Jantan (Mus Musculus). Jurnal Ilmiah Ibnu Sina, Vol. 01, No. 02, Hlm 131-142.

Akpuaka, M.U and S.N. Ezem, june 2011. Preliminary photochemical screening of some Nigerian dermatological plants. Journal of Basic Physical Research ISSN ; 2141-8403 Vol. 2, No. 1, pp 1-5, www.jbasicphyres-unizik.org 